\title{
SPRAWOZDANIE Z 24. SYMPOZJUM EMPIRYCZNEJ PEDAGOGIKI RELIGIJNEJ AKRK
}

DOI: http://dx.doi.org/10.12775/TiCz.2020.031

W dniach 5-7 marca 2020 roku odbyło się w Norymberdze 24. międzynarodowe sympozjum empirycznej pedagogiki religijnej zorganizowane w ramach sekcji Pedagogiki Religijnej Arbeitsgemeinschaft Katholische Religionspädagogik/Katechetik. Uczestniczyli w nim przedstawiciele z pięciu państw.

W czwartek 5 marca odbyła się pierwsza część sympozjum adresowana do doktorantów skupiona wokół dwóch zagadnień. Dr Nicole Bauer z Uniwersytetu w Innsbrucku przedstawiła pola badawcze i metody oceny w empirycznej pedagogice religijnej. Chodzi tu o metody stosowane po zebraniu danych empirycznych $w$ realizowanych badaniach. Na podstawie tych metod uzyskane dane należy odpowiednio ocenić i przeanalizować. Następnie PD dr Christian Höger z Freiburga przedstawił zagadnienie kodowania ankiet. PD dr Christian Höger omówił kodowanie otwarte w sensie ugruntowanej teorii za pomocą programu Maxqda oraz przedstawił praktyczne przykłady badań wykorzystujące tę metodę. Główną zasadą ugruntowanej teorii jest to, że teorie badaczy na dany temat są konstruowane na podstawie uzyskanych danych. Innymi słowy, zbierając i analizując dane jakościowe, badacze mogą opracować nową teorię „na 
podstawie" tych danych. Ugruntowana teoria zaczyna się zatem od gromadzenia danych na podstawie pytania, a nie w celu przetestowania hipotezy. Podstawy tej metodologii sformułowali w 1967 roku socjologowie Barney Glaser i Anselm Strauss w książce The Discovery of Grounded Theory.

Następnego dnia przed południem były trzy wystąpienia. Pierwszy zabrał głos Jens Schwarzkamp z uniwersytetu w Bochum. Przedstawił on wyniki badań empirycznych zrealizowanych na temat orientacji nauczycieli religii wobec uczniów-uchodźców uczestniczących w lekcji religii. Prowadząc badania, chciał poznać, jaka jest postawa nauczycieli religii wobec uczniów-emigrantów pochodzących z różnych religii. Potem zaprezentował uzyskane wyniki i ich analizę. Zauważył, że w szkole spotykają się określone orientacje wobec religii zarówno nauczycieli, jak i uczniów. Między katolikami a ewangelikami nie ma różnic w odniesieniu się do uczniów-uchodźców. Muzułmanie obecni na lekcji religii uczą się nowych określeń typowych dla życia chrześcijańskiego i języka niemieckiego. To pomaga im odnajdować się w nowym dla nich środowisku kulturowym.

Potem Sarah Delling z uniwersytetu w Siegen przedstawiła wyniki badań nad tematem związanym $\mathrm{z}$ inscenizacją komunikacyjną $\mathrm{w}$ lekcji religii - „Prezentacja narzędzia analizy/obserwacji”. Autorka skupiła się na zagadnieniu komunikacji, jaka odbywa się na lekcji religii. Aby poznać właściwości tej komunikacji, wykorzystała obserwację prowadzoną za pomocą kamery telewizyjnej. Nagrała około trzydzieści różnych fragmentów lekcji i poddała je analizie. Przedmiotem jej analizy były zarówno wypowiedzi uczniów, jak i mowa ich ciała.

Następnym referentem był Saulo Quintana Gomes z uniwersytetu z Campinas w Brazylii. Przedmiotem jego zainteresowania jest nauczanie religii i zapoznawanie z wynikami nauki w kontekście szkolnym. Dla niego problemem badawczym było zagadnienie, jaki stosunek uczniów kształtuje przekazywanie wiedzy z nauk przyrodniczych i uczenie lekcji religii w szkole. Na początku XX wieku spotykamy się z przeciwstawieniem wiedzy z nauk przyrodniczych i treści religijnych. Nabrzmiewający konflikt między wiedzą a wiarą, podkreślał Saulo Quintana Gomes, był inspiracją dla Piusa XII, aby pokazać, że istnieją także pozytywne relacje między wiedzą a wiarą. Stopniowo to doprowadziło do pojawienia się dialogu między przedstawicielami świata nauk ścisłych i teologii. W wyniku prowadzenia tego dialogu pojawiła się teologia naturalna. Autor 
starał się więc poznać, jak wśród uczniów postrzegana jest relacja między wiedzą a wiarą. Przeprowadził on badania porównawcze w Brazylii i Niemczech. Starł się poznać, jaki jest stosunek uczniów do omawianej kwestii uczących się w szkołach Waldorffa, w szkołach wyznaniowych i szkołach publicznych.

Po południu zaplanowane były cztery wystąpienia. Pierwszy zabrał głos ks. dr hab. Kazimierz Skoczylas, prof. UMK z Polski Przedstawił on możliwość katechezy seniorów w Polsce w kontekście ich aktywności. W Polsce narasta liczba osób w wieku poprodukcyjnym. Wielu zachowuje dobre zdrowie. Stąd dzisiejsi seniorzy, po zakończeniu pracy zawodowej, są otwarci na różne aktywności. Wśród nich jest wiele przejawów aktywności inspirowanej ich religijnością. Należy tu między innymi angażowanie się w wolontariat, turystykę, działalność uniwersytetów trzeciego wieku czy w działalność religijną inspirowaną przez różne formy duszpasterstwa. W tym kontekście autor wypowiedzi przedstawił, jakie możliwości stwarzają te aktywności, aby rozszerzyć ich wiedzę religijną i pogłębić życie religijne.

Kolejnym mówcą w sesji popołudniowej był dr Egbert van Dalen z uniwersytetu w Nijmegen w Holandii. Mówił o interpretacji kryzysu u pacjentów chorych na nieuleczalną chorobę nowotworową. Problemem badawczym było pytanie, jak ludzie nieuleczalnie chorzy na nowotwór interpretują swoją chorobę, jaką rolę odgrywa w tym ich religijność. W interpretacji tego zjawiska wykorzystał pojęcie „Kontingenzerfahrung”. Przeprowadzane badania wskazały na trzy obszary interpretacji swojej choroby przez badanych. Wskazywali, że choroba powstała w wyniku określonej przyczyny, niepewnej przyczyny albo niemożliwe jest wskazanie przyczyny. Stąd część badanych pacjentów nie znajdowała wytłumaczenia dla przyczyny ich choroby, następna grupa traktowała swoją chorobę jako nieoczekiwane zdarzenie, a część przeżywała jako tragedię, która prowadzi do bezradności.

W sesji popołudniowej również dr Michael Scherer-Rath z uniwersytetu w Nijmegen w Holandii dokonał prezentacji metody nowego projektu badawczego. Po nim wystąpił dr Christian Fröhling z Filozoficzno-Teologicznej Szkoły Wyższej św. Grzegorza we Frankfurcie i mówił o empirycznych badaniach wyobrażeń uczniów ze szkół katolickich dotyczących ich perspektyw. 
W sobotę Laura Mössle z uniwersytetu w Tübingen mówiła o możliwości tworzenia okoliczności do przeżywania emocji w lekcji religii. Następnie głos zabrał ks. dr Piotr Halczuk z uniwersytetu w Wiedniu. Omówił on założenia rozprawy habilitacyjnej realizowanej w Instytucie Katolickiej Teologii Praktycznej uniwersytetu w Wiedniu. Celem jego badań było zmierzenie kompetencji międzyreligijnych uczniów klas ósmych szkół podstawowych uczęszczających na lekcje religii w diecezji gnieźnieńskiej.

Formularz badawczy wykorzystany w badaniach składa się z dwóch części: ankiety oraz testu, który został dwukrotnie przeprowadzony, przed i po tzw. Interwencji, czyli lekcjach religii na temat dialogu międzyreligijnego. Narzędzie badawcze zostało przez niego opracowane m.in. na podstawie książki Georga Ritzera pt. Interesse - Wissen - Toleranz - Sinn, Berlin 2010.

Celem prowadzonych badań było zmierzenie dotychczasowych „doświadczeń międzyreligijnych” zebranych przez uczniów zarówno w środowisku szkolnym (tj. w ramach nauczania religii), jak i pozaszkolnym (tj. w domu, poprzez media). W części ankietowej chodziło o zmierzenie „poczucia własnej wartości” uczniów w konkretnych dziedzinach.

Drugie narzędzie badacze, czyli test, został opracowany zwłaszcza na podstawie książki zbiorowej po redakcją Dietricha Bennera, Rolfa Schiedera, Henniga Schlussa i Joachima Willemsa zatytułowanej Religiöse Kompetenz als Teil öffentlicher Bildung, Paderborn 2011. Ta publikacja posłużyła autorowi do przygotowania założeń teoretycznych narzędzia. Natomiast do przygotowania treści testu były wykorzystane polskie publikacje autorstwa Marka Jasińskiego i Mirosława Tykfera, Dialog Międzyreligijny - wybrane tematy, Poznań 2011 i Dialog międzyreligijny, Kim jest Bóg?, Imiona Boga, Wyznania wiary, Jezus z Nazaretu, Mahomet pod redakcją Aleksandry Bałoniak i Anny Zellmy oraz Księgi Święte- wybrane tematy: Święte Księgi, Talmud, Koran, Biblia, Poznań 2013.

Celem drugiego narzędzia było zmierzenie kompetencji międzyreligijnych, które uczniowie nabyli w trakcie nauczania religii, tzw. specjalnie przygotowanej interwencji. W dalszej części swego wystąpienia autor przedstawił wstępne wyniki i wskazał na pierwsze próby interpretacji uzyskanych wyników. 
Sympozjum zakończyło jego podsumowanie. Tematyka podejmowanych badań była bardzo rozległa i zarazem niezwykle interesująca. Organizatorzy stworzyli szerokie spektrum wymiany międzynarodowej i możliwość poznania zainteresowań badawczych podejmowanych w innych krajach w ramach pedagogiki religijnej. 